\title{
LYME BORRELIOSIS - RISK OF OCCUPATIONAL INFECTION
}

\author{
Bochnickova Maria, Szilagyiova Maria,
}

Clinic of Infectology and Travel Medicine, Jessenius Faculty of Medicine and University Hospital, Martin, Slovak Republic

\begin{abstract}
Lyme borreliosis is the most frequent anthropozoonosis in the Northern Hemisphere. The primary vector of disease transmission is the tick Ixodes ricinus (in Europe), and given its seasonal activity, the highest incidence of the disease early stages is in summer. People professionally exposed to a tick and other insect bite have a higher prevalence of positive serum antibody levels compared to the general population. The aim of this prospective study was to determine the levels of positive antibodies in professional soldiers after a tick bite, and also to determine the risk of occupational infection - Lyme disease.

We analyzed the serum samples taken from 95 professional soldiers, who were exposed to ticks in July 2010. The sera were taken 6 weeks after the exposure to ticks (Ixodes) in the mountains of Javorie. The ELISA method was used to examine the sera at the Institute of Microbiology in Ruzomberok, General Military Hospital. In the case of positive antibodies against Borrelia burgdorferi, the Western blot method was used. The risk of infection was $6.31 \%$.
\end{abstract}

Key terms: Lyme borreliosis, Borrelia burgdorferi, Ixodes ricinus, ELISA, Western Blot

\section{INTRODUCTION}

Over the last decades we have observed a rise in the incidence of Lyme disease (LD) due to climate, economic, and social changes. The number of recorded zoonoses is increasing also due to a rapid development of diagnostic methods. When speaking of Lyme borreliosis (LB), the issue is not a new epidemic, but disease recognition. Borreliosis is currently the most frequent anthropozoonosis in both Europe and the US, primarily transmitted by ticks. The infection is manifested by a multisystem impairment of the patient's organism, with a great variability of clinical symptoms that mutually overlap, and thus it deserves to be marked as a great imitator of several diseases. The causative agent of Lyme disease is a spirochete of the Borrelia burgdorferi complex sensu lato (Bb), whose forms are different in both the phenotypic and genotypic ways: Borrelia garinii, Borrelia afzeli, and Borrelia burgdorferi sensu stricto. Among the latest isolated species belong B. spielmani, B. lusitaniae, and B. valaisiana. The primary vector of these spirochetes is a tick of the Ixodes genus, in Europe the case mostly is Ixodes ricinus. In Europe the borrelial infection of ticks ranges from $0 \%$ to $85 \%$, in Slovakia the range is between $3-20 \%$, with an average of $8 \%$ (1). The highest rate of infected ticks $-20.2 \%$, was detected in Slovakia in the mountain oak-hornbeam forests with a moderate climate. On the contrary, their presence was not detected in cool coniferous forests (2). In epidemiological terms it is very interesting to notice that the infections have a cyclical character and occur in $3-5$ year intervals (3).

LB clinical symptoms have heterogeneous and multi-system manifestations, and their characteristic feature is mutual overlapping. The main clinical symptoms of this disease include an early skin condition ( erythema migrans - EM ), muscoskeletal symptoms, and rarely a lymphocytoma. In later stages a patient may develop neurological symptoms, the heart, joints and rarely eyes become affected, and chronic skin changes occur.

Address for correspondence:

Maria Bochnickova,MD.,MPH., 03101 Liptovsky Mikulas. Str. J. Janosku No. 1,

Mobile: +421 0908492 935, e-mail: mbochnickova@gmail.com 
A reliable diagnosis of $L D$ is generally difficult and usually problematic, mainly due to a multisystem clinical symptomatology, its variability, and mutual overlapping. Therefore, the basis of LB diagnosis is a clinical picture and a laboratory confirmed infection.

Nowadays the standard diagnostic methods mostly use the most recommended enzymelinked immunosorbent assay ( ELISA ), which enables to determine individual immunoglobulin IgM and IgG classes. The production of IgM antibodies starts $2-4$ weeks after the onset of infection, peaks after 6-8 weeks, and then a conversion to IgG antibodies occurs. Although in the majority of patients these antibodies disappear, several cases have occurred where both IgM and IgG antibodies persist for years, despite successful treatment. In professions like forest and agriculture workers, veterinary doctors, soldiers, but also tourists, significantly higher antibody levels were detected (4 - 7). To confirm an infection, the Western blot method is commonly used. A decrease in antibody levels may be slow, and therefore it is pointless to perform a control blood sample assay sooner than a period of $3-6$ months is over $(8,9)$.

\section{MATERIAL AND METHODS}

In a prospective study of positive antibodies against Borrelia in a risk groups, the observed sample consisted of 95 professional soldiers: 68 men (72\%) and 27 women (28 $\%$ ). The group was exposed to a tick bite in the month of July in the area of Javorie in Central Slovakia, at an altitude below $1000 \mathrm{~m}$ above sea level. They were educated in advance about the prevention against Lyme disease, which mainly includes the daily skin control and finding the latching ticks, which we removed lege artis in order to prevent the latching from lasting more than 24 hours. In order for an infection to develop, the length of latching is important. Six weeks after the expose ended, blood samples were taken from the examined group of people in order to determine the presence of antibodies against Borrelia burgdorferi in serum. The enzyme-linked immunosorbent assay (ELISA) was selected and performed at the Institute of Microbiology, General Military Hospital in Ružomberok. The Western blot method was only used to confirm the exam results in the case of a positive result, and to perform exact antibody detection against individual antigens. The patients underwent repeated physical examinations in order the symptoms indicating an early stage of Borrelia infection to be detected in time.

\section{RESULTS}

The sample consisted of 95 soldiers, of whom 68 were men (72\%) and 27 women (28\%). We collected anamnestic data on tick latching and removed the mite in 36 (38\%) cases, that is more than a third of the participants. Out of all 36 bitten people, 26 were men (38 $\%)$ and 10 were women (37\%), which as a result did not show any significant gender difference when speaking of tick bites. In all the examined patients, the results showed positive antibodies against $\mathrm{Bb}$ present in 25 cases (26\%). The group with positive patients consisted of 19 men (76\%) and 6 women (24\%). Out of the entire number of 68 men, 19 were found positive ( $28 \%$ ), of the female group (27 women), 6 women were found with positive antibodies (22\%) 6 weeks after their stay in a risk environment. In 22 positive cases the IgM antibodies were found (88\%). Two men were found positive for IgG antibodies only (8\%), and 1 man was found positive for both - IgM and IgG antibodies (4\%). Examination by the Western blot method confirmed the presence of Lyme disease in 5 cases : in 4 men (4.21\%) and 1 woman (1.05\%). In one person only clinical symptomatology was the case, and her serum results were negative. The risk of infection in the sample of 95 people was $6.31 \%$.

Clinical symptoms included the typical erythema migrans in none of the cases. Conversely, borrelial lymphocytoma as a rare skin demonstration of borrerial infection was discovered in one male case. This time the lymphocytoma was found on his auricle, and the infection was 
manifested by gastrointestinal symptomatology. All the 5 patients with both, positive antibodies and WB, complained of flu like symptoms: weakness, headache, fatigue, perspiration.

Doxycycline treatment ( $200 \mathrm{mg} \mathrm{1x}$ / day ) was initiated in 4 men with a positive WB, and in 1 man with clinical symptoms of Lyme disease - early localized stage, with serologic negativity, lasting as long as 28 days. One woman was administered Doxycycline $200 \mathrm{mg}$ in one dose after the tick removal, given the size of the tick and the length of latching around 12 hours. After administration of this preventive dose, the level of WB antibodies was borderline.

\section{DISCUSSION}

Lyme borreliosis currently is a public, health, social and economic problem, not only in Slovakia. One hundred new infections are recorded annually with an increasing tendency. The real number can only be assumed, because the records are not accurate, the patients themselves often underestimate the symptoms, and Lyme disease imitates a number of other conditions. According to a German rheumatologist, Dr. S. Schnar, the recorded borreliosis cases only represent one seventh of the actual number of the afflicted patients (10). An assumed occurrence in Slovakia is more than 1000 new infections annually. Increase in their number is attributed to global warming, since moderate winters give a chance for more infected rodents and ticks to survive. Ticks can even survive in higher altitudes compared to what the case was in the $80^{\prime}$ s of the $20^{\text {th }}$ century, when they could not be found above $800 \mathrm{~m}$ above sea level (11). The risk of infection varies and is dependent on the occurrence of infected ticks, their sucking habits, occurrence of one-year hosts, and its development varies depending on different geographic locations. All these are facts that explain the geographic and seasonal distribution of Lyme disease. The disease occurs all year long; however, it has a seasonal character, and its incidence is dependent on tick activity, season, and activity of people (12). Tick activity is mainly influenced by microclimate and relative air humidity. Ideal conditions would mean air humidity higher than $80 \%$. Therefore, ticks can survive in higher grass where the relative air humidity is maintained in higher temperatures as well (13). The incidence of the disease is higher in spring and summer months. In terms of seasonality, the increased activity of adult ticks peaks twice - between April and June, and in September. In the meantime, only the lower developmental stages of ticks (mainly nymphs) become more active (14).

For the development of infection, the length of latching is important - a minimum of 24 hours. If the latching lasts more than 48 hours, the risk of infection transmission is 50 $\%$, after 72 hours of latching, the risk increases to $100 \%$ (15). However, if a bite comes from a hibernated tick contaminated with Borrelia, the infection can be transmitted after a very short latching period (16).

Several studies resulted in significantly elevated levels of antibodies against Bb, mainly in the professional groups of forest and agricultural workers, and soldiers $(7,23,24)$. We also looked for the gender differences in the tick acquirement, but we did not found any. Gern, L. (17) speaks about mites being attached to the male population more often; our research resulted in $38 \%$ male hosts and $37 \%$ of female hosts (17). Tick biting was only recorded in $38 \%$ of all the exposed people. In the month of July, the less developed stages become more active, especially nymph ticks that easily escape attention, and after feeding they eventually drop off the host. In order for an infection to develop, the length of latching is important - a minimum of 24 hours (15). However , none of the 6 patients, in whom the Lyme disease developed, had a tick latched for more than 20 hours, and the disease started in spite of this. If the latching lasts more than 48 hours, the risk of infection transmission is $50 \%$, after 72 hours of latching, the risk increases to $100 \%$ (17). Therefore we educated the participants of the training about the preventive measures, so as to minimize the tick latching length as much as possible.

The Western blot positivity values in one female case were borderline, and with no significant symptomatology. We assign this finding to a single preventive $200 \mathrm{mg}$ dose of Doxycycline following the tick extirpation, which in her case was latched for about 12 hours. This 
kind of preventive and efficient method of giving a single dose was introduced by a study performed in the US (18). Erythema migrans, which is a Lyme disease early stage typical symptom, was not detected in any of the cases. In the 90's the occurrence of erythema in Lyme disease was $60-80 \%(19,20)$. Over the last years, erythema occurs in $40 \%$ of cases, especially in younger age categories (21). A frequent antibiotic treatment in children may suppress the skin symptoms of Lyme disease. Early disease stage may have a latent course, and in these cases the risk of transition into disseminated forms of disease is higher. All the 5 positive patients fell in that category. Given that the disease originated later, we will repeat the serological examinations of antibodies against $\mathrm{Bb}$ in all the 26 positive patients after 3 months. Our study still continues. In 1/3 of the patients diagnosed with the Lyme arthritis, erythema migrans can only occur during the disseminated infection (10).

One man manifested the clinical symptoms even before the laboratory examination was performed. Non-specific gastro-enteritis would have been assigned to a different disease, if a detailed physical examination had not revealed borrelial lymphocytoma on the right auricle, and the Doxycycline treatment had not been immediately initiated and administered for 21 days. Western blot test was negative in this particular patient.

Out of the 5 men, in whom the Lyme borreliosis was confirmed, one had already overcome the infection in the past. At the same time, in two of his relatives - men, the disease has been present, which confirms the association with HLA class antigens (22).

Doxycycline is the first choice treatment in the early stage of the disease, and is administered for as long as 28 days. As soon as the therapy is over, it is recommended to perform a control blood sample assay in no less than 3 months' time.

Table 1. Summary of the most commonly occurring antigens of Bb (Western blot method)

\begin{tabular}{|l|l|}
\hline Antigens of Bb. & The seropositivity \\
\hline $\mathrm{p} 17$ & 1 \\
\hline $\mathrm{p} 21$ & 2 \\
\hline $\mathrm{p} 25$ & 3 \\
\hline $\mathrm{p} 30$ & 1 \\
\hline $\mathrm{p} 31$ & 3 \\
\hline $\mathrm{p} 39$ & 2 \\
\hline $\mathrm{p} 83$ & 2 \\
\hline VlsE & 2 \\
\hline
\end{tabular}

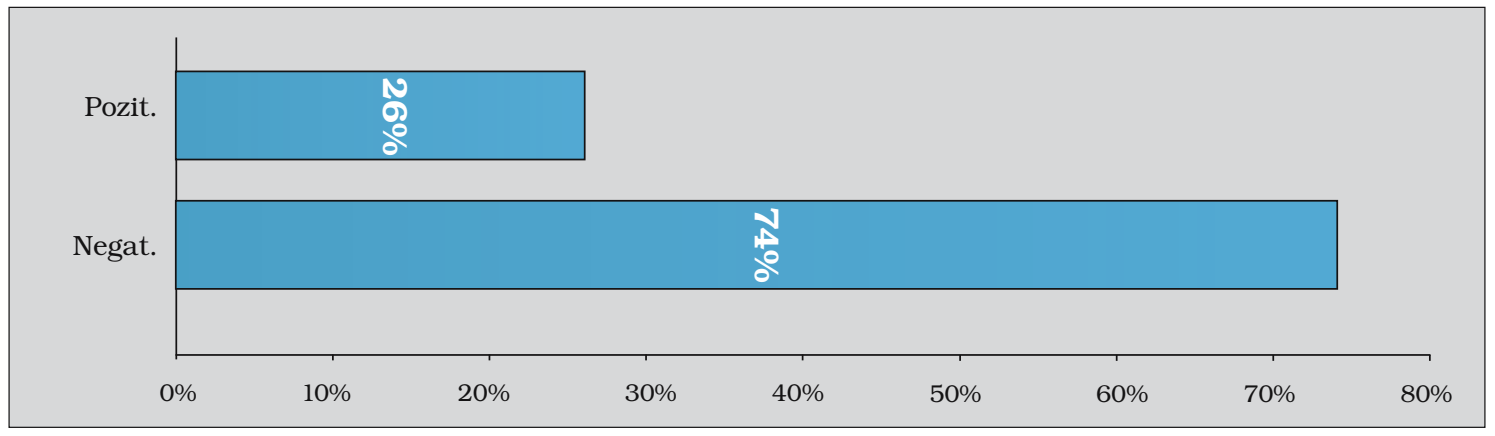

Fig. 1 Distribution of the patients according to $\mathrm{Bb}$ antibodies positivity 


\section{CONCLUSION}

A prospective study with 95 people confirmed the seropositivity of $\mathrm{Bb}$ antibodies in the risk exposed population of soldiers in $26 \%$ of cases. No gender differences in tick acquirement were confirmed, mites were latched in $38 \%$ of men and $37 \%$ of women. Risk of Lyme disease when exposed to a blood-sucking animal was in 6 people out of 95, that means $6.31 \%$. Positive antibodies against $\mathrm{Bb}$ were found in 25 people (26\%), 19 men (28\%) and 6 women (22\%).

\section{REFERENCES}

1. Pet'ko B, Stanko M, Nadzamová D, Štepánová G, Siuda K, Karbowiak G. Výskyt genospecies Borrelia burdorferi ss.1. v klieštoch Ixodes ricinus Karpatskej a Perikarpatskej oblasti Slovenska a Pol’ska. Klieštami prenášané infekčné choroby $2001 ; 28$.

2. Pet'ko B. Ekológia Borrelia burgdorferi sensu lato v Európe. In: Klieštami prenášané infekčné choroby a iné zoonózy 2001; 21.

3. Kmety E, Macháčová E, Výrosteková V, Kontrošová S. Incidencia Lymskej boreliózy na Slovensku. In: Klieštami prenášané infekčné choroby a iné zoonózy $2001 ; 20$.

4. Staněk G, Strle F. Lyme borreliosis. The Lancet 2003; 362: 1639- 47.

5. Tomao P, Ciceroni L, D`Ovidio MC, De Rosa M, Vonesch N, Iavicoli S, Signorini S, Ciarrocchi S. Prevalence and incidence of antibodies to Borrelia burgdorferi and to tick-borne encephalitis virus in agricultural and forestry workers from Tuscany, Italy. European Journal of Clinical Microbiology \& Infectious diseases 2005; 24 (7): $457-63$

6. Nahimana I, Gern L, Blanc DS, Praz G, Francioli P, Péter O. Risk of Borrelia burgdorferi infection in western Switzerland following a tick bite. European Journal of Clinical Microbiology \& Infectious diseases 2004; 23 (8): $603-8$.

7. Bartuněk P, Gorian K, Mrázek V, Vavejka P, Hulínská D, Janovská D. Information value of detection of borrelia antibodies in the healthy blood donors et in a population in the risk. Journal of Chinese Clinical Medicine 2007; 2 ( 5 ): $252-8$.

8. Wilske B. Epidemiology and diagnosis of Lyme borreliosis. Annals of Medicine 2005; 37 : 568 - 79.

9. Singh SK, Girschick HJ. Lyme borreliosis. Clinic Microbiology infectology 2004; $10: 598-614$.

10. Schnarr S. et al. Lyme borreliosis. Best Practice \& Research Clinical Rheumatology 2006; 6: 1099 - 118.

11. Bullová E, Lukáň M, Petkko B. New data on the distribution of Ixodes ricinus in Central Europe. Results of field survey in Slovakia 2008. Zborník abstraktov z konferencie.

12. Maetzel D, Maier WA, Kampen H. Borrelia burgdorferi infection prevalences in questing Ixodes ricinus ticks in urban and suburban Bonn. Western Germany. Parasitology 2005; 95: 5 - 12.

13. Gray JS. The ecology of tick transmitting Lyme borreliosis. Experimental \& Applied Acarology 1998; $22: 249$ - 58.

14. Hrkl’ová G, Štefančíková A, Revallová M, Petko B. Liptov - horské ohnisko lymskej boreliózy. Parazitologické dni 2010, 34 .

15. Gavorník P, Bazovská S. Uštipnutie klieštom v praktickej klinickej medicíne. Slovenský lekár 2002; 5-6: $213-15$.

16. Derdáková M, Lenčáková D. Association of genetic variability with the Borrelia burgdorferi s.1. with the ecology, epidemiology of Lyme borreliosis in Europe. Ann Agric Environ Medicine 2005; 12 : 165 - 72.

17. Gern L. The biology of the Ixodes ricinus tick. Revue therapeutique 2005; 62: 707 - 12 .

18. Nadelman RB. et al. Prophylaxis with Single-Dose Doxycycline for the Prevention of Lyme Disease after an Ixodes scapularis Tick Bite. The New England Journal of Medicine 2001; 345: 79

19. Zoschke D. Is it Lyme disease ? Postgradual Medicine 1992; 7: 46 - 55.

20. Wormser GP. Early Lyme disease. The New England Journal of Medicine 2006; 354: 2794 - 801.

21. Tveitnes D, Oymar K , Natas O . Laboratory data in children with Lyme neuroborreliosis, relation to clinical presentation and duration of symptoms. Scandinavia Journal Infect diseases 2009; 41 : 355 - 62.

22. Steere CA . Lyme borreliosis in 2005, 30 years after initial observations in Lyme Connecticut. The Middle European Journal of Medicine 2006; 118 (21-22): 625-33.

23. Buchancova J, Hudeckova H, Murajda L, Švihrova V, Bátora I, Legáth L', Osina O, Vilček R, Jakubovičová E. Lymská borelióza z pohladu pracovného lekárstva - porovnávajúca štúdia. Pracovní lékařství 2009; 2: 46 - 55.

24. Jakubovičová E, Buchancová J, Klimentová G. Profesionálna lymská borelióza na Slovensku a v stredoslovenskej oblasti. Slovenský lekár 2007; 17 ( 31 ); 5-6 : 111.

Received: November, 9, 2010

Accepted: January, 20, 2011 